\title{
Epigenetic propagation of CD4 expression is established by the $C d 4$ proximal enhancer in helper $T$ cells
}

\author{
Mark M.W. Chong, ${ }^{1,3}$ Natalie Simpson, ${ }^{1}$ Maria Ciofani, ${ }^{1}$ Grace Chen, ${ }^{1}$ Amélie Collins, ${ }^{1}$ \\ and Dan R. Littman ${ }^{1,2,4}$ \\ ${ }^{1}$ The Kimmel Center for Biology and Medicine at the Skirball Institute, New York University School of Medicine, New York, \\ New York 10016, USA; ${ }^{2}$ Howard Hughes Medical Institute, New York University School of Medicine, New York, \\ New York 10016, USA
}

\begin{abstract}
The stability of a lineage program (cellular memory) is dependent on mechanisms that epigenetically maintain active or repressed states of gene expression (transcriptional memory). Although epigenetic silencing of genes has been clearly demonstrated from yeast to mammals, heritable maintenance of active transcription has been less clearly defined. To investigate the potential role of active transcriptional memory during lineage diversification, we employed targeted mutation of a positive-acting cis element in the $\mathrm{Cd} 4$ locus to determine the impact on CD4 expression and the differentiation of $\mathrm{CD}^{+}$helper $\mathrm{T}$ cells in mice. We show that the proximal enhancer $\left(E 4_{P}\right)$ of $C d 4$ is essential for $\mathrm{CD} 4$ expression in immature $\mathrm{CD}^{+} 8^{+}$thymocytes. Futhermore, its loss resulted in reduced and unstable expression of CD4 in mature T cells. However, if the enhancer was deleted after cells had already committed to the helper T-cell lineage, CD4 expression remained high and was stable upon cell division. "Active" histone modifications, once initiated by $E 4_{P}$, were also propagated independently of the enhancer. Thus, $E 4_{P}$ is responsible for establishing an epigenetically inherited active $C d 4$ locus in the helper T-cell lineage. To our knowledge, this is the first genetic demonstration of active transcriptional memory in mammalian cells.
\end{abstract}

[Keywords: Epigenetics; transcription; chromatin; gene regulation; CD4; T-cell development]

Supplemental material is available at http://www.genesdev.org.

Received January 4, 2010; revised version accepted February 23, 2010.

The formation of diverse tissues and organ systems during development requires the heritable propagation of distinct programs of gene expression in each type of differentiated cell. These programs are generated and maintained by epigenetic mechanisms that are only partially understood. The differentiation from multipotent thymic progenitors of $\mathrm{T}$ lymphocytes with distinct phenotypes and immune system functions has provided a valuable developmental system for studying how heritable gene expression is initiated and maintained. $\mathrm{CD}^{+}$helper $\mathrm{T}$ cells and $\mathrm{CD} 8^{+}$ cytotoxic $\mathrm{T}$ cells are each derived from progenitors that express both the CD4 and CD8 coreceptors (termed "double-positive" or DP cells). Investigation of coreceptor expression, which is tightly linked to the functional program of the mature cells, has provided valuable insight into transcriptional mechanisms involved in the lineage bifurcation. Because of the convenient phenotypic characterization of T-cell subsets, they have also proved to be

${ }^{3}$ Present address: The Walter and Eliza Hall Institute of Medical Research, Parkville, Victoria 3052, Australia.

${ }^{4}$ Corresponding author.

E-MAIL dan.littman@med.nyu.edu; FAX (212) 263-1498.

Article is online at http://www.genesdev.org/cgi/doi/10.1101/gad.1901610. ideal to study mechanisms of heritability of transcription states, or transcriptional memory, during cell lineage diversification.

The most immature thymocytes, double-negative (DN) cells, express neither CD4 nor CD8. Rearrangement of the Tcrb locus that results in expression of the $\beta$ subunit of the T-cell antigen receptor (TCR) is followed by upregulation of both CD4 and CD8 at the DP stage, during which the Tcra locus is rearranged (Berg and Kang 2001). The few DP thymocytes that express an $\alpha \beta$ TCR of appropriate avidity for self-peptide-major histocompatibility complexes (MHC) undergo positive selection, whereupon they down-regulate CD8 expression to exhibit the $\mathrm{CD} 4{ }^{+} 8^{\text {lo }}$ phenotype. These transitional cells then differentiate into either $\mathrm{MHCI}$-specific $\mathrm{CD}^{+}$single-positive (CD8SP) or MHCII-specific CD4 ${ }^{+}$single-positive (CD4SP) thymocytes through processes regulated by the transcription factors Runx3, GATA3, and ThPOK (for review, see Collins et al. 2009).

Expression of the $C d 8 a$ and $C d 8 b$ genes is regulated by multiple enhancers acting coordinately in a developmental stage- and lineage-specific manner (Ellmeier et al. 1997, 1998; Hostert et al. 1997, 1998). In contrast, a large 
body of data suggested that the $C d 4$ gene may be regulated simply by a proximal enhancer $\left(E 4_{P}\right)$ and an intronic silencer $(S 4)$ that activate and repress transcription, respectively. Early analysis of DNaseI-hypersensitive sites within the $C d 4$ locus in murine T-cell lines led to the identification of the regulatory element $E 4_{P}$, a 339base-pair (bp) fragment lying $13 \mathrm{~kb}$ upstream of the CD4 transcriptional start site (Sawada and Littman 1991). This element from either the murine or human gene was sufficient to direct CD4 reporter expression in almost all thymocytes and in all TCR $\alpha \beta^{+}$cells, but not in other lineages (Gillespie et al. 1993; Killeen et al. 1993; Hanna et al. 1994; Sawada et al. 1994).

The $E 4_{P}$ element has the potential to be active in all $\mathrm{TCR} \alpha \beta^{+}$thymocytes and T cells, but is restricted by the activity of $S 4$, which represses expression of $E 4_{P}$-directed transgenes in $\mathrm{DN}$ and $\mathrm{CD} 8 \mathrm{SP}$ thymocytes and $\mathrm{CD} 8^{+} \mathrm{T}$ cells (Sawada et al. 1994; Siu et al. 1994). Germline deletion of endogenous $S 4$ confirmed its requirement in repressing CD4 expression in DN thymocytes and $\mathrm{CD} 8^{+}$ $\mathrm{T}$ cells (Zou et al. 2001). However, silencing was unaffected when a conditional $S 4$ allele was deleted in mature $\mathrm{CD} 8^{+} \mathrm{T}$ cells, indicating that, once CD4 silencing is established in mature T cells, it is epigenetically inherited independently of $S 4$ (Zou et al. 2001). We subsequently showed that Runx transcription factors bind to $S 4$, and that Runx1 is required for active CD4 repression in DN thymocytes, while Runx3 is required for establishing epigenetic silencing in $\mathrm{CD}^{+}{ }^{+} \mathrm{T}$ cells (Taniuchi et al. 2002).

Together, E4 $4_{\mathrm{P}}$ and $\mathrm{S} 4$ are sufficient to direct the expression of numerous transgenes in a manner that closely parallels expression of the endogenous $C d 4$ gene. For example, human $\mathrm{CD} 2$ or cre recombinase under the control of these two elements are expressed only in DP thymocytes and mature CD4 ${ }^{+} \mathrm{T}$ cells (Sawada et al. 1994; Wolfer et al. 2001). However, a role for additional elements was suggested by a study in which another enhancer, termed the "thymocyte enhancer" $\left(E 4_{T}\right)$, was reported to be necessary in conjunction with $\mathrm{E} 4_{\mathrm{P}}$ to direct expression of reporter transgenes in DP thymocytes (Adlam and Siu 2003). $E 4_{T}$ lies $36 \mathrm{~kb}$ downstream from the $C d 4$ gene within the first intron of the Usp5 gene. Furthermore, it has been shown that activation of mature $\mathrm{T}$ cells results in the downregulation of a transgenic reporter under the control of $E 4_{P}$ and the Cd4 promoter (Manjunath et al. 1999), suggesting that another enhancer may be required for maintaining $\mathrm{CD} 4$ expression in antigen-stimulated $\mathrm{CD} 4^{+} \mathrm{T}$ cells.

While the function of the CD4 silencer $S 4$ has been clearly demonstrated by targeted mutagenesis, the functions of the various enhancers have only been inferred from transgenic studies. Moreover, it has not been determined if positive transcriptional regulation, like silencing, can be propagated in an epigenetically heritable manner. Thus, targeted deletion is required to clearly delineate the functions of Cd4-associated enhancers. Here we show that $E 4_{P}$, but not $E 4_{T}$, is essential for expression of CD4 at the DP stage and for its sustained expression in mature $\mathrm{CD} 4^{+} \mathrm{T}$ cells. We also demonstrate that, similar to the function of the CD4 silencer in $\mathrm{CD} 8^{+}$ $\mathrm{T}$ cells, $E 4_{P}$ is no longer required once cells have com- pleted differentiation into mature $\mathrm{CD} 4^{+} \mathrm{T}$ cells. Activity of $E 4_{P}$ was coupled to the deposition within $C d 4$ of active histone modifications that were subsequently propagated independently of $E 4_{P}$. Our findings thus indicate that $E 4_{P}$ is responsible for establishing an epigenetically inherited active state of CD4 expression following positive selection of MHCII-restricted thymocytes.

\section{Results}

$E 4_{P}$ is required for $C D 4$ expression in $D P$ thymocytes and contributes to CD4 expression

in mature $T$ helper cells

Mice in which $E 4_{P}$ was flanked by $\operatorname{Lox} P$ sites were generated $(F$ allele), and were used to produce a null allele $(\Delta)$ by cre-mediated deletion in the germline (Supplemental Fig. S1). Thymocyte development was first examined in mice homozygous for deletion of the enhancer. Expression of $\mathrm{CD} 4, \mathrm{CD} 8$, and other markers was analyzed by flow cytometry to distinguish specific developmental stages (Fig. 1A). The mutant mice displayed a disrupted thymocyte CD4/CD8 expression profile. There was loss of the DP population and a marked reduction in the percentage of CD4SP thymocytes (Fig. 1B), although the total cell numbers in the thymus and peripheral lymphoid organs were unaffected (data not shown). By subdividing the thymocyte developmental stages, CD4 expression was found to be absent from preselection DP thymocytes, defined by the TCR $\beta^{\text {lo }} \mathrm{TCR} \gamma \delta^{-}$phenotype. However, CD 4 expression was present in post-positive selection thymocytes $\left(\mathrm{TCR} \beta{ }^{\mathrm{hi}} \mathrm{CD} 24^{\mathrm{hi}} 69^{+}\right)$, and was maintained in a population of CD4SP mature thymocytes (TCR ${ }^{\text {hi }} \mathrm{CD} 24^{\mathrm{lo}} 69^{-}$). The cis element $E 4_{P}$ is therefore essential for initiating CD4 expression at the DP immature thymocyte stage.

Although CD4 was re-expressed in post-selection thymocytes and maintained in mature "CD4 $4^{+"}$ cells in $E 4_{P}{ }^{\Delta / \Delta}$ mice, it was expressed at approximately one-third of the level in wild-type cells, and with a much broader distribution as assessed by flow cytometry (Fig. 1B,C; Supplemental Fig. S2). Consistent with the flow cytometry results, CD4 mRNA was absent in mutant DP-staged thymocytes, but was detected following positive selection, and was maintained in mature CD4SP thymocytes at approximately one-third of the level in wild-type cells (Fig. 1D). In contrast, $\mathrm{CD} 8 \alpha$ transcription was unaffected in mutant mice (Supplemental Fig. S3). Therefore, $E 4_{P}$ also contributes to CD4 expression in mature T helper cells.

The lack of CD4 expression at the DP stage in $E 4_{P}{ }^{\Delta / \Delta}$ mice did not affect the frequency of positively selected TCR $\beta{ }^{\text {hi }} \mathrm{CD} 24^{\text {hi }} 69^{+}$or $\mathrm{TCR} \beta{ }^{\text {hi }} \mathrm{CD} 24^{\mathrm{lo}} 69^{-}$thymocytes (data not shown), or of TCR $\beta^{+}$splenocytes (Supplemental Fig. S2), but resulted in an inversion of the CD4SP:CD8SP ratio (Fig. 1B; Supplemental Fig. S2). Expression of the transcription factor ThPOK is repressed in DP thymocytes (He et al. 2008; Setoguchi et al. 2008) and is up-regulated in post-selection thymocytes (He et al. 2005; Sun et al. 2005). ThPOK is critical for the generation of mature $\mathrm{T}$ helper cells, and its deficiency results in redirection of MHCII-selected thymocytes toward the CD8SP lineage 
A
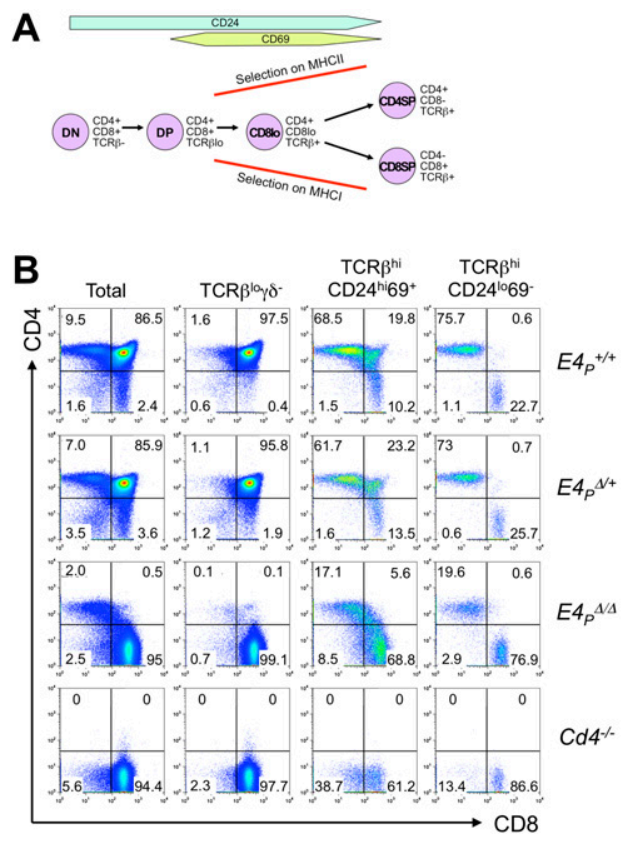

C

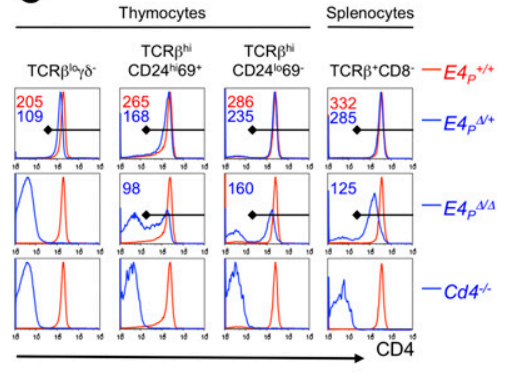

D

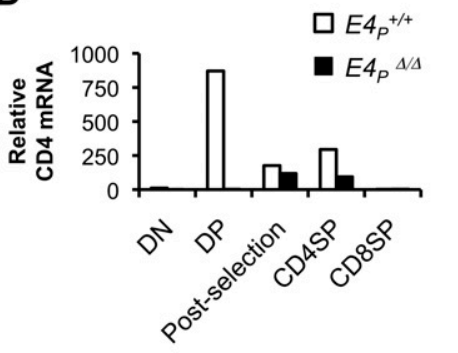

Figure 1. The $C d 4$ "proximal enhancer" $\left(E 4_{P}\right)$ is required for CD4 expression in immature DP thymocytes, and contributes to expression in mature CD4SP thymocytes. (A) Stages of thymocyte development distinguished by the cell surface expression of CD4, CD8, and other markers. Selection on MHCII leads to $\mathrm{CD}^{+}$ helper T-cell differentiation, while selection on MHCI leads to $\mathrm{CD}^{+}$cytotoxic T-cell differentiation. $(B)$ Thymocytes from wild-type, heterozygous, and homozygous $E 4_{P}$-deficient and CD4-deficient mice were analyzed for CD4 and CD8 expression by flow cytometry. Shown is the expression on total, preselection $\left(\mathrm{TCR} \beta^{\mathrm{lo}} \gamma \delta^{-}\right)$, recently selected $\left(\mathrm{TCR} \beta{ }^{\text {hi }} \mathrm{CD} 24^{\text {hi }} \mathrm{CD} 69^{+}\right)$, and mature (TCR $\beta^{\text {hi }} \mathrm{CD} 24^{\text {lo }} \mathrm{CD} 69^{-}$) thymocytes. $(C)$ Histogram overlays of CD4 expression on preselected, recently selected, and mature thymocytes, and on TCR $\beta^{+}$ splenocytes. The inset numbers are the mean fluorescence intensity for the $\mathrm{CD} 4^{\mathrm{lo} /+}$ population in each histogram. $(D)$ RT-PCR analysis of CD4 transcript levels in DN, DPstaged $\left(\mathrm{CD} 8^{+} \mathrm{TCR} \beta^{\text {lo }} \mathrm{CD} 24^{\text {hi }} \mathrm{CD} 69^{-}\right)$, postselection $\left(\mathrm{TCR} \beta{ }^{\text {hi }} \mathrm{CD} 24^{\text {hi }} \mathrm{CD} 69^{+}\right)$, CD4SP, and CD8SP thymocytes.
(Keefe et al. 1999). It has been proposed that TCR-MHCII interaction derepresses ThPOK expression in post-selection thymocytes, thus directing their differentiation toward the helper lineage (He et al. 2008; Setoguchi et al. 2008). The inversion of the CD4:CD8 ratio in $E 4_{P}{ }^{\Delta / \Delta}$ mice could be a result of inadequate ThPOK induction caused by the lack of CD4 expression at the DP stage. However, there was no difference in the level of ThPOK mRNA expressed in postselection thymocytes and mature $\mathrm{CD}^{+(\mathrm{lo})} \mathrm{T}$ cells between $E 4_{P}{ }^{\Delta / \Delta}$ and wild-type mice (Supplemental Fig. S4A). The same result was also found using a ThPOK-GFP bacterial artificial chromosome (BAC) transgenic reporter mouse on the $E 4_{P}{ }^{\Delta / \Delta}$ background (Supplemental Fig. S4B). Therefore, CD4-dependent DP selection does not appear to be required for ThPOK derepression, and the inversion of the CD4:CD8 ratio in $E 4_{P}{ }^{\Delta / \Delta}$ mice does not correlate with a perturbation in ThPOK expression. The inverted ratio is likely due to inefficient selection of MHC class II-restricted cells due to reduced expression of $\mathrm{CD} 4$.

\section{$E 4_{T}$ is not required for CD4 expression in T cells}

Based on transgenic reporter studies, it has been suggested that another putative CD4 enhancer, which has been termed the "thymocyte enhancer," may be required in addition to $E 4_{P}$ for CD4 expression at the DP immature thymocyte stage (Adlam and Siu 2003). To investigate this possibility, $E 4_{T}$ was targeted sequentially in embryonic stem cells in which $E 4_{P}$ had already been flanked by LoxP sites. This yielded $E 4_{P}^{F / F} E 4_{T}{ }^{-/-}$mice, in which only $E 4_{T}$ was disrupted, and $E 4_{P}{ }^{\Delta / \Delta} E 4_{T}{ }^{-/-}$mice, in which both enhancers were disrupted (the derivation of these mice is described in more detail in the Materials and Methods). Deletion of $E 4_{T}$ alone had no effect on CD4 expression at any stage of thymocyte development or in mature T cells, while mice that lacked both $E 4_{P}$ and $E 4_{T}$ displayed the same phenotype as $E 4_{P}{ }^{\Delta / \Delta}$ mice (Supplemental Fig. S5A). Rather than contributing to CD4 expression in T cells, $E 4_{T}$ was required for CD4 expression in a subset of lymphoid tissue inducer (LTi) cells in the lamina propria of the small intestine (Supplemental Fig. S5B). E4 $4_{T}$ was also not required for CD4 expression in splenic dendritic cells (Supplemental Fig. S5C).

\section{E4 $4_{P}$-independent expression of CD4 following MHCI- and MHCII-dependent positive selection}

The expression of CD4 in E4 $4_{P}$-deficient post-positive selection thymocytes, coupled with previous results with reporter transgenes (Manjunath et al. 1999), suggests that at least one additional $C d 4$ enhancer functions during thymocyte maturation. The maturation of the $\mathrm{CD}^{+}$ helper or $\mathrm{CD}^{+}$cytotoxic T-cell lineages from DP thymocytes is intimately linked with selection on peptides embedded in MHCII or MHCI molecules (Supplemental Fig. S6A). Thus, to understand the requirements for activation of the remaining low-level CD4 in mature T cells of $E 4_{P}$-deficient mice, $E 4_{P}{ }^{\Delta / \Delta}$ mice were bred with MHCIdeficient $\left(B 2 \mathrm{~m}^{-/-}\right)$and MHCII-deficient $\left(\mathrm{H} 2-\mathrm{Ab1}^{-/-}\right)$ mice. Surprisingly, CD4 expression was observed at the post-selection thymocyte stage in both $E 4_{P}{ }^{\Delta / \Delta} \mathrm{H} 2-\mathrm{Ab} 1^{-/-}$ and $E 4_{P}{ }^{\Delta / \Delta} B 2 m^{-1-}$ mice (Supplemental Fig. S6B), indicating that TCR engagement with either MHCI or MHCII activates a late transcriptional element in the $C d 4$ gene. Similar to $H 2-A b 1^{-/-}$mice, the mature CD4SP and peripheral $\mathrm{CD} 4^{\text {lo }} \mathrm{T}$-cell populations were largely lost in $E 4_{P}{ }^{\Delta / \Delta} H 2-A b 1^{-/-}$mice (Supplemental Fig. S6B,C), indicating that the $\mathrm{CD} 4^{\mathrm{lo}} \mathrm{T}$ cells in $\mathrm{E} 4_{\mathrm{P}}$-deficient mice 
are indeed selected by interaction with MHCII, despite a lack of CD4 expression at the DP thymocyte stage.

The finding that selection by either MHCI or MHCII activates CD4 expression in selected thymocytes of $E 4_{P}{ }^{\Delta / \Delta}$ mice suggests that a $C d 4$ "maturation enhancer(s)" or a positive epigenetically regulated element (e.g., the promoter) may also remain active in mature $\mathrm{CD}^{+} \mathrm{T}$ cells, but this would be masked by activity of the silencer S4. To examine whether enhancer activity still occurs in CD8 lineage cells when silencing is eliminated, mice bearing an $E 4_{P}{ }^{F / F}$ conditional allele (Supplemental Fig. S7) were bred with $C b f b^{F / F} C D 4$-cre mice (Naoe et al. 2007) in order to abrogate Runx protein function from the DP stage onward. $C b f b^{F / F} C D 4$-cre mice displayed derepressed CD4 expression in $\mathrm{CD}^{+} \mathrm{T}$ cells, as was shown previously, while $E 4_{P}{ }^{F / F} C D 4$-cre mice phenocopied the germline deletion (Supplemental Fig. S8). In $E 4_{P}^{F / F} C b f b^{F / F} C D 4$-cre double-conditional mice, a population of $\mathrm{CD} 4^{\mathrm{lo}} 8^{+} \mathrm{DP} \mathrm{T}$ cells was observed in the mature thymocyte compartment and the spleen, indicating that the activity of a putative CD4 "maturation enhancer" is maintained in the CD8 lineage. This suggests that there is interaction of $S 4$ with both $E 4_{P}$ and a post-selection regulatory element, and that epigenetic silencing of the $C d 4$ locus in the $\mathrm{CD} 8^{+}$cytotoxic lineage requires mechanisms to repress both elements.

\section{CD4 expression is unstable in mature T cells} of $E 4_{P}{ }^{-1-}$ mice

In the periphery of $E 4_{P}{ }^{\Delta / \Delta} B 2 \mathrm{~m}^{-/-}$mice there was a very high frequency of TCR $\beta^{+} \mathrm{T}$ cells that did not express either CD4 or CD8 (Supplemental Fig. S6C). Potentially, these could be derived from aberrantly selected thymocytes. Alternatively, the CD4 expression on CD $4{ }^{\text {lo }}$ T cells in $E 4_{P}{ }^{\Delta / \Delta}$ mice could be unstable, and these DN T cells may be derived from MHCII-selected cells that had previously expressed CD4. $E 4_{P}{ }^{\Delta / \Delta} B 2 \mathrm{~m}^{-/-}$mice displayed a

A

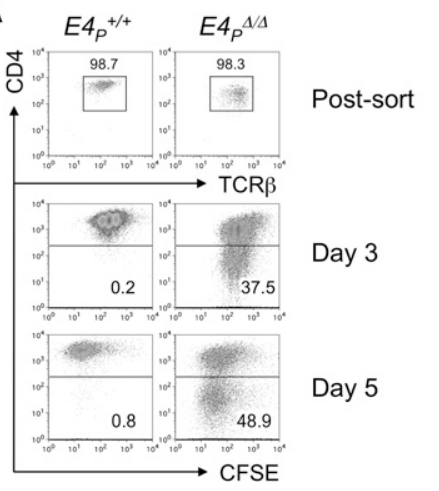

B

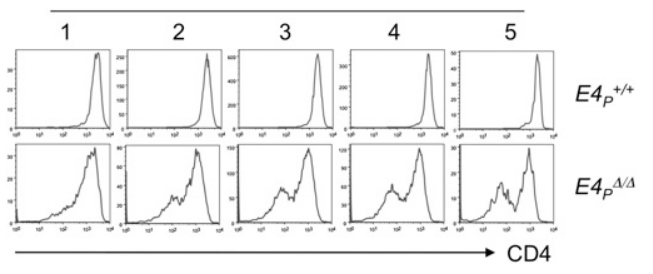

10-fold decrease in the frequency of TCR $\beta^{\text {hi }}$ thymocytes (data not shown), and the reduced mature thymocyte output resulted in lymphopenia-induced homeostatic proliferation in the periphery, as suggested by a high frequency of $\mathrm{CD} 44^{\text {hi }} 62 \mathrm{~L}^{\text {lo }} \mathrm{CD} 4{ }^{\text {lo }}$ cells (data not shown). Under such proliferative stress, CD4 expression could be lost. To examine this possibility, CD $4^{+/ 10} \mathrm{TCR}^{+}$cells from $E 4_{P}{ }^{\Delta / \Delta}$ and wild-type mice were purified by fluorescence-activating cell sorting (FACS), loaded with CFSE to track cell division, then activated in vitro with anti-CD3/ CD28 antibodies. Unlike $\mathrm{CD}^{+} \mathrm{T}$ cells from wild-type mice, CD $4^{\text {lo }} \mathrm{T}$ cells from $E 4_{P}{ }^{\Delta / \Delta}$ mice began to lose CD4 expression within two divisions following TCR activation (Fig. 2A,B). The proportion of $\mathrm{CD}^{-} \mathrm{T}$ cells also increased slightly with each subsequent division. A similar phenomenon was observed when congenic isotype-marked wild-type CD4 ${ }^{+}\left(\mathrm{CD} 45.1^{+}\right)$and $E 4_{P}{ }^{\Delta / \Delta} \mathrm{CD} 4^{\text {lo }}$ $\left(\mathrm{CD} 45.2^{+}\right) \mathrm{T}$ cells were adoptively cotransferred into lymphopenic Rag2-deficient hosts and CD4 expression was assessed at different times after transfer (Fig. 2C). Thus, the E4 $\mathrm{P}$ enhancer not only contributes to maximal CD4 expression in mature $\mathrm{CD} 4^{+} \mathrm{T}$ cells, but it is also required for stabilizing CD4 expression in these cells as they expand in the periphery.

\section{$E 4_{P}$ is required for initiating heritable high-level CD4 expression in thymocytes committed to the T-helper lineage}

We showed previously that the CD4 silencer is required for initiation, but not epigenetically heritable maintenance, of silenced CD4 expression in $\mathrm{CD}^{+} \mathrm{T}$ cells (Zou et al. 2001). The compromised stability of CD4 expression in the absence of $E 4_{P}$ was reminiscent of variegation, and raised the possibility that epigenetically inherited active states of CD4 expression might also exist. To investigate this, $\mathrm{CD}^{+} \mathrm{T}$ cells were FACS-purified from

Figure 2. Effect of $E 4_{P}$ deletion on the stability of CD4 expression in proliferating helper T cells. $(A)$ $\mathrm{TCR}^{+} \mathrm{CD}^{+/ 1 \mathrm{lo}}$ cells were FACS-sorted from spleen and lymph nodes of wild-type and $E 4_{P}$-deficient mice and loaded with $5 \mu \mathrm{M}$ CFSE. The cells were then activated in vitro with anti-CD3 and anti-CD28 antibodies. The cells were analyzed for CD4 expression after 3 and $5 \mathrm{~d}$ in culture. $(B) \mathrm{CD} 4$ expression in cells gated for CFSE levels shown in $A$ at day 3 of activation in vitro. $(C)$ TCR $\beta^{+} \mathrm{CD} 4^{+/ l o}$ cells were FACS-sorted from congenically marked wild-type (Cd45.1) and E4P-deficient (Cd45.2) mice, and were mixed together at a $1: 1$ ratio. The cells were then

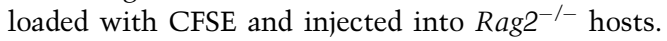
$\mathrm{TCR}^{+}$cells were analyzed for CD4 expression at 2 and 4 wk post-transfer. 
$E 4_{P}^{F / F}$ and wild-type mice, then activated in vitro with anti-CD3/CD28 antibodies. After $24 \mathrm{~h}$, the cells were transduced with a cre-CD90.1 bicistronic retrovirus, which mediated efficient recombination of the $E 4_{P}{ }^{F}$ alleles (Supplemental Fig. S9A). Cell surface CD4 expression remained unchanged in conditionally deficient cells even $5 \mathrm{~d}$ after transduction with the retrovirus (Fig. 3A). To investigate the long-term stability of CD4 expression in recombined $E 4_{P}^{F / F}$ cells, congenically marked wild-type $\left(\mathrm{CD} 45.1^{+}\right)$and $E 4_{P}{ }^{F / F}\left(\mathrm{CD} 45.2^{+}\right) \mathrm{CD}^{+} \mathrm{T}$ cells were first transduced with cre-GFP bicistronic retrovirus in vitro. Once deletion was confirmed (Supplemental Fig. S9B), the cells were mixed and adoptively cotransferred into lymphopenic Rag2-deficient hosts (Fig. 3B). Four weeks after adoptive transfer, the $\mathrm{CD} 4$ expression on $E 4_{P}$ conditionaldeficient cells was no different from that of wild-type cells. Thus, in contrast to CD4 lineage cells that exhibited unstable CD4 expression after differentiating in the absence of $E 4_{P}$, cells in which loss of $E 4_{P}$ was induced after maturation maintained stable levels of the coreceptor.

Epigenetic modification of the Cd4 locus by $E 4_{P}$ accompanies heritable high-level CD4 expression in the T-helper-cell lineage

The heritable expression of CD4 following induced deletion of $E 4_{P}$ in helper $\mathrm{T}$ cells suggested that the $\mathrm{Cd} 4$

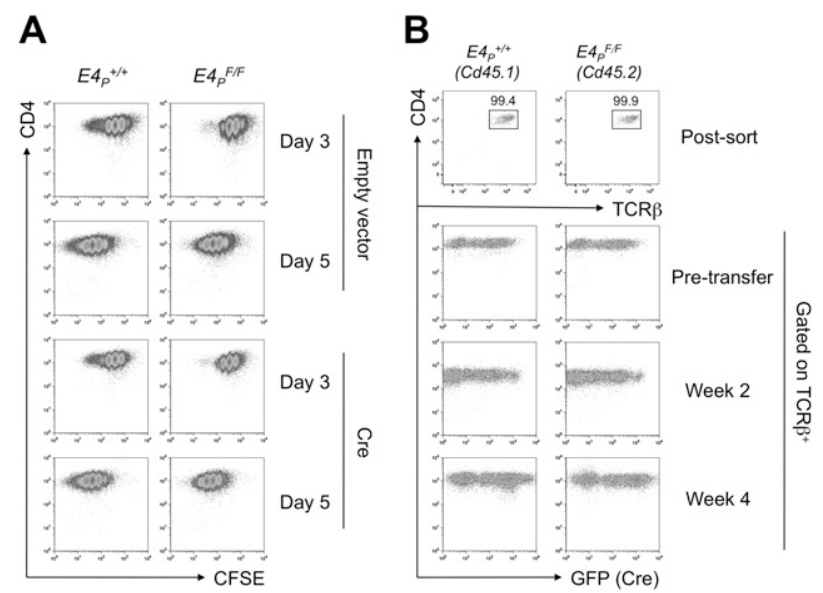

Figure 3. Role of $E 4_{P}$ in epigenetic maintenance of CD4 expression in helper T cells. $(A)$ TCR $\beta^{+} \mathrm{CD} 4^{+}$cells were FACS-sorted from the spleens and lymph nodes of wild-type and $E 4_{P}$ conditionaldeficient mice and loaded with $5 \mu$ M CFSE. The cells were then activated in vitro with anti-CD3 and anti-CD28 antibodies. Twenty-four hours after activation, the cells were transduced with a retrovirus encoding cre-IRES-CD90.1. After a further 3 or $5 \mathrm{~d}$ in culture, transduced cells (expressing CD90.1) were analyzed for CD4 expression. $(B)$ TCR $\beta^{+} \mathrm{CD} 4^{+}$were FACS-sorted from congenically marked wild-type (Cd45.1) and $\mathrm{E} 4_{\mathrm{P}}$ conditional-deficient (Cd45.2) mice and activated in vitro with anti-CD3 and antiCD28 antibodies. Twenty-four hours after activation, the cells were tranduced with a retrovirus encoding Cre-pgk-GFP. At $24 \mathrm{~h}$ after transduction, the cells were removed from anti-CD3/28 stimulation and allowed to rest for a further $24 \mathrm{~h}$. After a total of $72 \mathrm{~h}$ in culture, the $C d 45.1$ and $C d 45.2$ cells were mixed together in a 1:1 ratio and injected into $R a g 2^{-1-}$ hosts. TCR $\beta^{+}$cells were analyzed for CD4 expression at 2 and 4 wk post-transfer. locus was modified epigenetically by the enhancer during thymocyte maturation. We showed previously that DNA methylation does not play a role in $C d 4$ gene regulation (Zou et al. 2001). We therefore analyzed the Cd4 locus for histone modifications using quantitative chromatin immunoprecipitation (ChIP) analysis. The histone modifications analyzed included acetylation (H3Ac) and Lys 4 trimethylation (H3K4me3) of histone 3, marks for actively transcribed genes, and Lys 9 trimethylation (H3K9me3) and Lys 27 trimethylation (H3K27me3) of histone 3, marks for silenced genes. Total $\mathrm{H} 3$ was also analyzed to control for variations in nucleosome density along the $C d 4$ gene. Additionally, the deposition of the histone 2 variant $\mathrm{H} 2 \mathrm{AZ}$ was analyzed. H2AZ can correlate with either active or silenced genes, but in Saccharomyces cerevisiae, H2AZ has been found at the promoters of most genes located within euchromatin (Raisner et al. 2005).

Wild-type DP thymocytes displayed high levels of H3Ac and H3K4me3 marks in exon 1, and at the silencer S4 within intron 1 (Fig. 4A). The presence of H3Ac throughout is consistent with active transcription. However, the presence of $\mathrm{H} 3 \mathrm{~K} 4 \mathrm{me} 3$ at exon 1 and S4, but only low levels at the promoter, was unexpected, because it was shown previously that this modification is enriched specifically at the promoters of actively transcribed genes (Heintzman et al. 2007). Not surprisingly, $E 4_{P}$-deficient DP-stage thymocytes lacked both active marks throughout the $C d 4$ locus, whereas the $C d 8 a$ promoter in both the wild type and mutant was marked by $\mathrm{H} 3 \mathrm{Ac}$ and $\mathrm{H} 3 \mathrm{~K} 4 \mathrm{me} 3$. In wild-type mice, mature $\mathrm{CD}^{+} \mathrm{T}$ cells contained $\mathrm{H} 3 \mathrm{Ac}$ and $\mathrm{H} 3 \mathrm{~K} 4 \mathrm{me} 3$ at the $\mathrm{Cd} 4$ promoter. Mature $\mathrm{CD} 4^{\text {lo }} \mathrm{T}$ cells in $E 4_{P}$-deficient mice also acquired $\mathrm{H} 3 \mathrm{Ac}$ throughout the Cd4 locus, but had only low levels of $\mathrm{H} 3 \mathrm{~K} 4 \mathrm{me} 3$ at the promoter and within the gene. Mature $\mathrm{CD}^{+}{ }^{+}$cells in both wild-type and mutant mice lost $\mathrm{H} 3 \mathrm{Ac}$ and H3K4me3 throughout the Cd4 locus, but maintained them at the Cd8a promoter. Thus, the low level of CD4 expressed in mature MHCII-selected $\mathrm{T}$ cells of $\mathrm{E} 4 \mathrm{P}^{-}$ deficient mice correlates with relatively normal $\mathrm{H} 3 \mathrm{Ac}$ but a reduced level of H3K4me3 modification. In contrast to prominent perturbations in the "active" marks, only minor differences were observed for H3K9me3 and H3K27me3 between wild-type and mutant mice (Supplemental Fig. S10), indicating loss of active transcription rather than aberrant silencing of the $C d 4$ locus in the absence of E4p. Deposition of H2AZ was also found at the promoter of $C d 4$ in mature $\mathrm{CD} 4^{+} \mathrm{T}$ cells, but this was not affected by $E 4_{P}$ deficiency (Supplemental Fig. S10).

We next examined whether the active histone modifications at the $C d 4$ locus were propagated in actively proliferating cells. In proliferating wild-type $\mathrm{CD} 4^{+} \mathrm{T}$ cells, the pattern of $\mathrm{H} 3 \mathrm{Ac}$ and $\mathrm{H} 3 \mathrm{~K} 4 \mathrm{me} 3$ modifications remained unchanged compared with cells that had been analyzed ex vivo (Fig. $4 \mathrm{~B}$ ). However, the $\mathrm{CD} 4^{\mathrm{lo}} \mathrm{T}$ cells from $E 4_{P}$-deficient mice lost all H3Ac once activated. Those cells that continued to express low levels of CD4 maintained low levels of H3K4me3, while cells that lost all CD4 expression also lost all H3K4me3 throughout the $C d 4$ locus. Thus, $\mathrm{CD} 4^{\mathrm{lo}} \mathrm{T}$ cells that differentiate without $E 4_{P}$ are unable to maintain active histone modifications at the $C d 4$ locus upon cell division. 


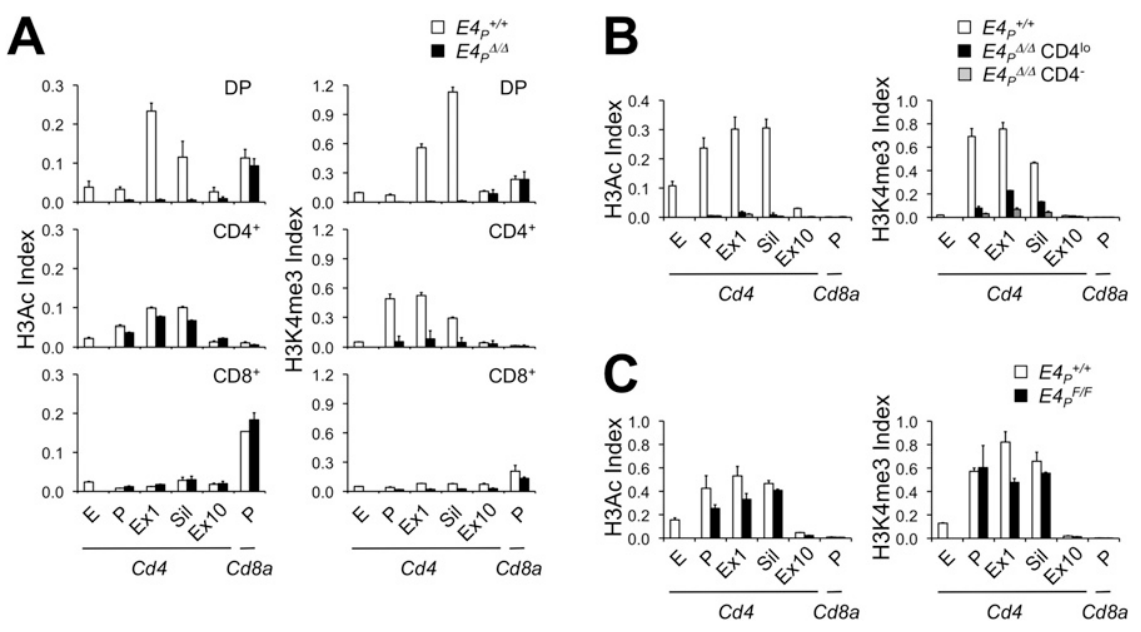

Figure 4. The impact of $E 4_{P}$ on histone modifications at the $C d 4$ locus during T-cell development. (A) "DP"-staged thymocytes (TCR $\left.\beta^{\text {lo }} \gamma \delta^{-} \mathrm{CD} 24^{\text {hi }} \mathrm{CD} 8^{+}\right)$and mature $\mathrm{CD}^{+/ / \mathrm{lo}}$ and $\mathrm{CD} 8^{+} \mathrm{T}$ cells from wildtype and $E 4_{P}$-deficient mice were analyzed for the transcriptionally active histone modification marks H3Ac and H3K4me3 by ChIP. Enrichment at $E 4_{P}(\mathrm{E})$, promoter $(\mathrm{P})$, exon 1 (Exl), silencer (Sil), and exon 10 (Ex10) of the Cd4 locus and the promoter of the $C d 8 a$ locus was analyzed by quantitative PCR. To account for variable histone density along the $C d 4$ locus, H3Ac or H3K4me3 ChIP efficiency (percent of input) was normalized to total $\mathrm{H} 3$ ChIP efficiency (percent of input). (B) Mature $\mathrm{CD}^{+/ 10} \mathrm{~T}$ cells were FACS-sorted from the spleen and lymph nodes of wildtype and $E 4_{P}$-deficient mice, and activated in vitro with anti-CD3 and anti-CD28 antibodies. After $5 \mathrm{~d}$, the cells in $E 4_{P}$-deficient cultures were sorted into those that had completely lost CD4 expression and those that had maintained CD $4^{\text {lo }}$ levels. These, together with wild-type $\mathrm{CD}^{+}$cells, were analyzed for $\mathrm{H} 3 \mathrm{Ac}$ and $\mathrm{H} 3 \mathrm{~K} 4 \mathrm{me} 3$ histone modifications by ChIP and quantitative PCR. (C) Mature $\mathrm{CD}^{+} \mathrm{T}$ cells were FACS-sorted from the spleens and lymph nodes of wild-type and $E 4_{P}$ conditional-deficient mice and were activated in vitro with anti-CD3 and anti-CD28 antibodies. Twenty-four hours after activation, the cells were transduced with a retrovirus encoding Cre-IRES-CD90.1. Following a further $4 \mathrm{~d}$ in culture, the CD90.1 $1^{+}$cells were sorted and analyzed for H3Ac and H3K4me3 histone modifications by ChIP and quantitative PCR. All data represent the mean \pm SEM of duplicates.

Finally, we examined the effect of deleting $E 4_{P}$ in fully mature $\mathrm{CD} 4^{+} \mathrm{T}$ cells. Consistent with the observed stable expression of CD4, loss of $E 4_{P}$ had no effect on $\mathrm{H} 3 \mathrm{Ac}$ and H3K4me3 modification at the $C d 4$ locus even in actively proliferating cells (Fig. 4C). Thus, once fully committed to the helper lineage, the histone modifications at the $\mathrm{Cd} 4$ locus are inherited independently of the enhancer that had initiated the modifications.

\section{Discussion}

In this study, we showed that an enhancer element, characterized previously as being T-cell-specific and able to direct expression of reporter genes throughout development of $\alpha \beta \mathrm{T}$ cells, is required for CD4 expression in DP thymocytes and for stabilization of CD4 expression following positive selection. Inactivation of this element, $E 4_{P}$, at different stages of development indicated that it functions epigenetically to establish a stable state of CD4 expression that, after positive selection, becomes independent of $E 4_{P}$ activity. Heritable expression of CD4 in the absence of the enhancer was accompanied by $C d 4$ locus histone modifications that are characteristic of active genes. These results complement our earlier study on the CD4 silencer and clearly illustrate that lineage specification in the course of animal development involves the stable establishment of both positive and negative states of transcriptional memory (Fig. 5). The former mechanism may differ from that of silencing, possibly involving cascades of enhancer activation. Thus, there may be an additional enhancer element that regulates CD4 expression in post-positive selection thymocytes and $\mathrm{T}$ cells, and such an element would likely interact with and be stabilized by $E 4_{P}$ early in development. Alternatively, $E 4_{P}$ may impart on the $C d 4$ pro- moter epigenetic properties that maintain it in an open and active configuration independently of another enhancer. Our previous transgenic studies showed that the promoter alone is insufficient to drive $C d 4$ transcription

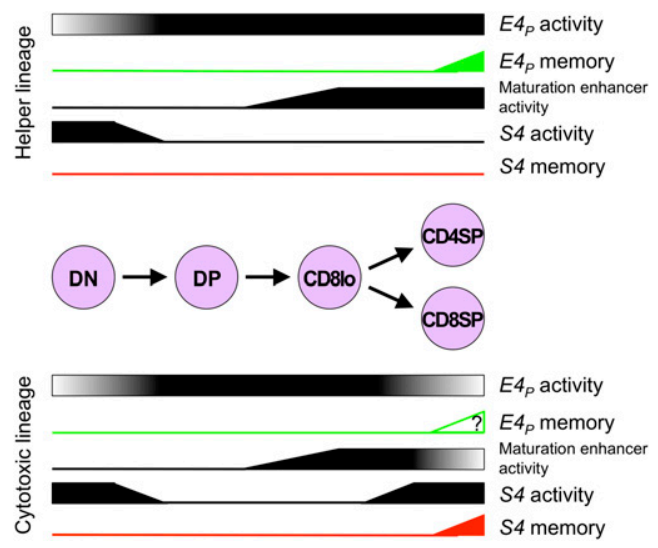

Figure 5. The timing of enhancer and silencer activity determines the expression of CD4 during thymocyte development. At the $\mathrm{CD} 4^{-} \mathrm{CD} 8^{-} \mathrm{DN}$ stage, $E 4_{p}$ has the potential to be active but is silenced by $S 4$. This repression of $E 4_{P}$ is then released at the $\mathrm{CD} 4^{+} \mathrm{CD} 8^{+} \mathrm{DP}$ stage, resulting in $\mathrm{CD} 4$ expression. Following selection of DP thymocytes toward the helper lineage, $E 4_{P}$ imparts an epigenetic mark that maintains active $C d 4$ transcription. $E 4_{P}$ is then no longer required for CD4 expression in mature helper T cells. Conversely, following selection down the cytotoxic lineage, the $C d 4$ locus is silenced epigenetically by $S 4$. The silenced $C d 4$ locus is then maintained in mature cytotoxic $\mathrm{T}$ cells independently of the $S 4$ element. Even though both $E 4_{P}$ and the putative maturation enhancer have the potential to be active in mature $\mathrm{CD} 8^{+} \mathrm{T}$ cells, they are silenced by this negative transcriptional memory. 
in either DP thymocytes or mature helper T cells (Sawada et al. 1994), but it is possible that its function in mature $T$ cells becomes independent of $E 4_{p}$. However, the finding that reporter gene expression under regulation of $E 4_{p}$ and the promoter is unstable following $\mathrm{T}$ cell activation (Manjunath et al. 1999) argues for the presence of at least one other enhancer directing expression of CD4 in mature $\mathrm{T}$ cells. The other enhancer is not the distal $3^{\prime}$ element $E 4_{T}$, which had been proposed to be required for expression of CD4 in DP thymocytes. $E 4_{T}$ was dispensable for CD4 expression in T cells, but was found to contribute to expression of CD4 in LTi cells. Expression of CD4 during T-cell development is thus likely to be regulated by multiple enhancers that function sequentially and in a coordinated manner, such that activity of an enhancer at one stage of development is manifested in transcription independent of the enhancer at a later stage.

\section{Enhancer requirements for CD4 expression in DP thymocytes}

The transcriptional regulatory activity of $E 4_{P}$, a 339-bp enhancer with binding sites for the basic helix-loop-helix (bHLH) transcription factors E2A and HEB (Sawada and Littman 1993), was identified originally in T-cell lines with phenotypes resembling immature thymocytes (Sawada and Littman 1991). In the absence of the CD4 intronic silencer, $E 4_{P}$ in combination with a short CD4 promoter, directs expression of transgenes in DN, DP, and all CD4 and CD8 lineage thymocytes and T cells (Sawada et al. 1994). Mice defective for expression of the bHLH transcription factors display arrested thymocyte differentiation and reduced expression of CD4 (Barndt et al. 1999; Jones and Zhuang 2007), consistent with a requirement for these factors in regulation of CD4 transcription. In all previous studies, the activity of $E 4_{P}$ was examined only in the context of transgenes or reporter assays, but its importance in the endogenous $C d 4$ locus was not assessed.

The present study showed that $E 4_{P}$ is indeed a critical CD4 enhancer in vivo. Together with results of earlier studies, we can conclude that $E 4_{P}$ is both necessary and sufficient for directing CD4 expression in DP thymocytes. In addition, the results also suggest the existence of at least one other enhancer that functions post-positive selection. Similar studies on the regulation of CD8 expression have shown that at least three different enhancers can direct reporter gene expression in DP thymocytes, but targeted removal of at least two of these is required to observe reduced or variegated expression of CD8 (Feik et al. 2005). Thus, multiple enhancer elements appear to be required for stage-specific expression of both CD4 and CD8.

The existence of additional $C d 4$ enhancers had been overlooked because $E 4_{P}$ alone has activity in mature $\mathrm{T}$ cells. However, $E 4_{P}$-dependent expression of a reporter gene was shown to be extinguished upon antigen-dependent activation of peripheral $\mathrm{T}$ cells (Manjunath et al. 1999), suggesting a requirement for another element that maintains CD4 expression in effector or memory T cells. Whether such an element is the same as a "maturation enhancer" implicated by the present study will need to be determined. The loss of CD4 or reporter expression in activated $\mathrm{T}$ cells from both $E 4_{P}$-deficient mice and $E 4_{P}$ transgenic mice suggests that there must be cooperation between $E 4_{P}$ and one or more other enhancers to ensure continued gene expression following T-cell activation. We cannot rule out, however, that $E 4_{P}$ modifies the $C d 4$ promoter such that it becomes constitutively active in a heritable manner. Our current results further suggest that, regardless of mechanism, the cooperation is needed only early in T-cell development.

Our findings further indicate that the Cd4 locus is regulated by distinct enhancers that function independently of each other in distinct lineages, including non-T cells. $E 4_{P}$ was found previously to be insufficient to direct gene expression in $\mathrm{CD}^{+}$monocytes, dendritic cells, or LTi cells (Kim et al. 2000), although it directed expression of transgenes in mouse myeloid lineages when combined with an intronic enhancer from human CD4 (Keppler et al. 2002). Since ablation of either $E 4_{P}$ or $E 4_{T}$ had no effect on CD4 expression in splenic dendritic cells, a distinct enhancer likely regulates myeloid-specific CD4 expression in mice. Likewise, $E 4_{T}$ contributes specifically to CD4 expression in LTi cells that are present in intestinal cryptopatches and isolated lymphoid follicles (Mebius 2003; Ivanov et al. 2006). We were unable to assign a role for this enhancer in other cell types, and cannot rule out that there are other regulatory elements with which it interacts to direct expression in the $\mathrm{CD}^{+}{ }^{+} \mathrm{LTi}$ cells. It will be of interest to determine if $E 4_{T}$ can be used as a tool for LTi-specific expression of transgenic products.

\section{A role for $E 4_{P}$ in establishment of epigenetic memory at the Cd4 locus}

Our results revealed an unexpected role played by $E 4_{P}$ in epigenetically modifying the $C d 4$ locus following thymocyte-positive selection. In the absence of $E 4_{P}$, CD4 expression was initiated immediately following selection of MHCI or MHCII-restricted thymocytes in the TCR $\beta^{+}$ $\mathrm{CD} 69^{+} \mathrm{CD} 24^{\text {hi }}$ compartment. However, the amount of CD4 expressed in thymocytes following positive selection and in mature T cells was reduced compared with that in wild-type mice. Furthermore, this expression was unstable, and CD4 was lost in cells undergoing proliferation. $E 4_{P}$ is therefore required for controlling both the level and the stability of CD4 transcription following positive selection.

$E 4_{P}$ was no longer required once $T$ helper cells emigrated from the thymus, as expression of CD4 was unaffected when it was inducibly deleted in peripheral T cells. When helper $\mathrm{T}$ cells developed in the absence of $E 4_{P}$, the $C d 4$ locus was not appropriately marked with histone modifications associated with active transcription; namely, $\mathrm{H} 3 \mathrm{Ac}$ and H3K4me3. However, once these modifications were made, we found that $E 4_{P}$ was no longer required to maintain them. This suggests that $E 4_{P}$ initiates a cascade of events that imposes an active transcriptional state at the Cd4 locus, which likely includes the recruitment of epigenetic machinery that modifies histones heritably to maintain an open chromatin configuration. This may then allow a putative "maturation enhancer" or a heritably 
active promoter to continue to direct expression efficiently and independently of $E 4_{P}$. Alternatively, $E 4_{P}$ and another enhancer needed for maintenance of CD4 expression may cooperate following positive selection to initiate the epigenetic mark, and no enhancer may be needed subsequently. Characterization of one or more additional enhancers and of trans-acting factors that bind to them will be required to resolve this issue.

A heritable active state of CD4 expression in helper T cells may be related to the heritable CD4 silencing that occurs in cytotoxic T cells. We showed previously that, once CD4 silencing is established in mature CD8 ${ }^{+}$T cells, it is epigenetically inherited independently of the S4 element (Zou et al. 2001). The activity of Runx proteins, particularly Runx3, is required during thymocyte selection for establishing this epigenetic silencing, but not for subsequent maintenance of the silent state ( $\mathrm{T}$ Egawa, MMW Chong, and DR Littman, unpubl.). Transcription factors that direct the heritable activation of CD4 expression in mature $\mathrm{T}$ helper cells are, in contrast, not yet defined. The HLH factors E2A and HEB appear to be involved in regulating $E 4_{P}$-dependent transcription in DP cells, but whether they also function to establish stable high-level heritable expression in peripheral $\mathrm{T}$ cells remains to be determined.

Signals to establish epigenetically heritable active or silenced Cd4 transcription could be linked to selection on MHC. The mechanism by which DP thymocytes commit to either the CD4 helper or the CD8 cytotoxic lineage based on interactions with MHC class II or class I, respectively, remains a major unresolved problem in developmental immunology. Although qualitatively distinct signals may be transmitted based on CD4-MHCII and CD8-MHCI interactions, there is also evidence that quantitative differences in TCR signaling may be key in the lineage decision (Singer 2002). Even though selection on either MHCI or MHCII activates the putative $C d 4$ maturation enhancer, it is possible that qualitative and/or quantitative differences result in distinct signals that modify the $C d 4$ locus.

The ability of the $C d 4$ locus to be epigenetically marked by either an activating or silencing element is reminiscent of so-called cellular memory module (CMM)-controlled genes in Drosophila melanogaster. CMMs are essentially chromosomal fragments containing both activating and silencing cis elements, not unlike the $C d 4$ gene. In Drosophila, the activity of these CMMs is controlled by the interplay between Polycomb group (PcG) and Trithorax (Trx) complexes binding to Polycomb response elements (PREs) or Trx responses elements (TREs). Transgenic studies have shown that PRE/TREs can maintain silenced or active gene expression states through many cell divisions independently of the initiating factors (Pelegri and Lehmann 1994; Cavilli and Paro 1998; Maurange and Paro 2002). This cross-regulation between Trx and PcG complexes is required for the appropriate expression and epigenetic regulation of homeotic genes, such as the Hox clusters, during embryonic development, and is conserved from Drosophila to mammals (Yu et al. 1995). In addition to early embryonic development,
Trx complexes may also contribute to epigenetic maintenance of gene expression in adult tissues. Mice deficient in one copy of the Mll gene, which encodes for a mammalian homolog of Trx with intrinsic H3K4 methyltransferase activity, were able to mount normal Th2 effector responses, but were unable to maintain the Th2 phenotype in memory T cells (Yamashita et al. 2006). Gata3 and Th2 cytokines were expressed normally in effector cells, but were lost in memory cells of $\mathrm{Mll}^{+/-}$ mice. Furthermore, H3K4me3 modification at these loci was also reduced in the $\mathrm{Mll}^{+/-}$memory T cells. Whether Mll also participates in the epigenetic propagation of CD4 expression in mature helper $\mathrm{T}$ cells is unclear, because $\mathrm{MII}^{+/-}$mice displayed normal CD4 and CD8 expression profiles, and homozygous mutant mice could not be examined due to early embryonic lethality (Yamashita et al. 2006). Other approaches, such as conditional inactivation of both Mll alleles at different stages of T-cell development, will be required to address this issue.

The epigenetic regulation of CD4 expression in T cells could potentially be viewed as under the control of a CMM. As discussed earlier, CD4 expression in myeloid lineages and LTi cells is independent of E $4_{P}$. Might expression or silencing of CD4 in these other lineages be propagated in an epigenetic manner as well? If so, an enticing possibility is that a single gene, such as $C d 4$, might contain multiple CMMs that function independently to impart appropriate heritable expression/silencing in different lineages.

Curiously, we found high levels of H3K4me3 in exon 1 and intron 1 of $C d 4$ in both DP and mature CD4 ${ }^{+}$T cells of wild-type mice. H3K4me3 is thought to be a specific marker for active promoters (Barski et al. 2007). However, in DP thymocytes, promoter-associated H3K4me3 was lower than in exon1 and intron 1. Promoter-associated H3K4me3 reached levels comparable with those found further downstream in the gene only in mature $\mathrm{CD}^{+} \mathrm{T}$ cells. The presence of $\mathrm{H} 3 \mathrm{~K} 4 \mathrm{me} 3$ through most of the $8 \mathrm{~kb}$ of intron 1 has also been observed in $\mathrm{T}$ helper cells by ChIP sequencing (Wei et al. 2009). Potentially, this unusual distribution of $\mathrm{H} 3 \mathrm{~K} 4 \mathrm{me} 3$ may be related to mechanisms of epigenetic activation (or silencing) of this locus during lineage commitment.

Together, our findings demonstrate that multiple enhancers are engaged sequentially to establish and maintain CD4 expression in T helper cells, and suggest a much more dynamic regulation of CD4 expression during thymocyte lineage commitment than had been appreciated previously. We also showed that the Cd4 locus is a target of both epigenetic silencing and activation mechanisms, and that these are intricately linked to the process of lineage commitment. Although there is a basic understanding of mechanisms that contribute the epigenetic silencing of genes, far less is understood about those that epigenetically maintain active transcription. Regardless of the mechanisms involved, we believe that this finding with CD4 gene regulation represents the first demonstration of transcriptional memory for a positively regulated genetic locus. Whether this is a common occurrence in development or is a rare specialized function will require further investigation. A recent study by Rudensky and coworkers 
(Zheng et al. 2010) showed that targeted mutation of a cis element termed CNS2 resulted in unstable Foxp3 transcription in regulatory T cells. Although this study did not go on to genetically test whether active Foxp3 transcription is inherited epigenetically, this finding suggests that active transcriptional memory may also be a feature of other genes in addition to Cd4. Further characterization of the cis elements and trans-acting factors involved in these processes is likely to provide significant insight into the differentiation of the various T-cell lineages and, more generally, into the mechanisms by which cell identity is fixed during lineage diversification, including those that establish and maintain transcriptional memory.

\section{Materials and methods}

Mice

A targeting vector containing a LoxP-flanked $E 4_{P}$ and a neomycin selection cassette (Neo) was assembled from genomic fragments amplified by PCR from a BAC clone containing the $C d 4$ locus. A LoxP-E4P-LoxP-Neo-LoxP configuration was employed such that cre-mediated recombination between the middle and 3' LoxP sites would yield a conditional allele, while recombination between the $5^{\prime}$ and $3^{\prime}$ LoxP sites would yield a null allele. An XbaI site was inserted at the $5^{\prime} \operatorname{Lox} P$ site to allow for screening by Southern blot. The construct was targeted into E14 129Oladerived embryonic stem cells, from which mice were derived. These were bred with EIIA-cre mice, which transiently express cre in the early embryo, to obtain progeny harboring either the conditional allele or null allele.

A second targeting vector in which $E 4_{T}$ was replaced with a Frtflanked hygromycin selection cassette $(\mathrm{Hyg})$ was assembled from PCR-amplified genomic fragments. EcoRI and BglII sites were inserted at the $5^{\prime}$ and $3^{\prime}$ ends of the selection cassette, respectively, to allow for screening by Southern blot. This construct was electroporated into E14 cells in which $E 4_{P}$ had already been flanked with $\operatorname{Lox} P$ sites. Mice derived from these cells were bred with EIIA-cre mice to obtain the $E 4_{P}{ }^{F} E 4_{T}^{\text {hyg }}$ and $E 4_{P}{ }^{\Delta} E 4_{T}^{\text {hyg }}$ alleles. These were then bred to Rosa26 ${ }^{F l p e}$ mice to remove the Frt-flanked Hyg. Primer sequences used to prepare targeting vectors are available on request.

A ThPOK-GFP reporter construct was generated by inserting eGFP at the ATG initiating codon in ThPOK within the RP23126P10 BAC (Roswell Park Cancer Institute). Transgenic mice were generated by microinjecting the modified BAC into C57BL/ 6 zygotes. Two independent lines with overlapping GFP expression were obtained.

$C b f b^{F / F}, C d 4^{-/-}$, and CD4-cre mice have been described previously (Killeen et al. 1993; Wolfer et al. 2001; Naoe et al. 2007). EIIA-cre, Rosa26 Flpe, and Cd45.1 mice were purchased from Jackson Laboratories, and $\mathrm{H} 2-\mathrm{Ab}^{-/-}, \mathrm{B2m}^{-/-}$, and $\mathrm{Rag}^{-/-}$ mice were purchased from Taconic Farms. All analyses and experiments were performed on animals at $6-8 \mathrm{wk}$ of age. They were housed in SPF conditions at the animal facility of the Skirball Institute. All animal experiments were performed in accordance with approved protocols for the New York University Institutional Animal Care and Usage Committee.

\section{Organ preparation}

Lymphocytes were prepared from thymi, spleens, and lymph nodes by grinding the organs through a $100-\mu \mathrm{m}$ mesh. Dendritic cells were prepared from spleens by digesting the organs in 200 $\mu \mathrm{g} / \mathrm{mL}$ Collagenase D (Sigma) in RPMI (Invitrogen) supplemented with $10 \%$ FCS (Hyclone) for $1 \mathrm{~h}$ at $37^{\circ} \mathrm{C}$, then grinding through a $100-\mu \mathrm{m}$ mesh. Red blood cells were removed from splenic cell suspensions by lysis with ACK buffer (BioWhittaker).

Small intestinal lamina propria lymphocytes were prepared by dissecting the organs longitudinally in cold PBS to expose the lumen, and thoroughly washing with PBS. The organs were then incubated in $5 \mathrm{mM}$ EDTA in PBS for $20 \mathrm{~min}$ at $37^{\circ} \mathrm{C}$ with gentle rotation, after which the epithelial layer was removed by shaking for $1 \mathrm{~min}$. The organs were rinsed with fresh PBS, then cut into 1-cm lengths and transferred into RPMI 10\% FCS containing 200 $\mu \mathrm{g} / \mathrm{mL}$ Collagenase D and $100 \mu \mathrm{g} / \mathrm{mL}$ DNaseI (Sigma). They were digested for $1.5 \mathrm{~h}$ at $37^{\circ} \mathrm{C}$ with gentle rotation, then dispersed by vigorous shaking for $5 \mathrm{~min}$. The cell suspension was filtered through a $100-\mu \mathrm{m}$ mesh and resuspended in a $40 \%$ Percoll (GE) solution overlaid with an $80 \%$ Percoll solution. After centrifugation at $2500 \mathrm{rpm}$ for $20 \mathrm{~min}$ at room temperature, the lymphocytes were collected from the interface.

\section{Cell sorting and flow cytometry}

Bulk $\mathrm{CD}^{+}$populations were purified using MACS anti-CD4 magnetic beads (Miltenyi Biotech). To achieve highly purified homogeneous populations, these bulked preparations were further FACS-sorted on a FACSAria (BD Biosciences). Flow cytometric analyses were performed on an LSRII (BD Biosciences). Antibodies for cell sorting and analyses were purchased from eBiosciences or BD Pharmingen.

\section{Quantitative RT-PCR}

Total RNA was prepared using TRIZOL (Invitrogen), and first strand reverse transcription was performed using SuperScript II (Invitrogen). cDNA was analyzed by quantitative PCR in triplicates by using QuantiTect Multiplex PCR mix (Qiagen) on the Bio-Rad iCycler. $\beta$-Actin was measured using the primers $5^{\prime}$-GCTCTGGC TCCTAGCACCAT-3' and 5'-GCCACCGATCCACACAGAGT-3', and probeFAM-TCAAGATCATTGCTCCTCCTGAGCGC-TAMRA. ThPOK was measured using the primers 5 ' - TGCTTCCGCATGTG GATC- 3 ' and 5' - GTGAGAAGCCCTTTGCCTGT-3', and probe FAM-TGGTGAAGCGGACGCCGCA-BHQ-1 (He et al. 2005).

\section{Plasmids and retrovirus production}

The ORF of Cre was cloned into MSCV-IRES-CD90.1. MSCVCre-pgk-GFP has been described previously (Zou et al. 2001). Plat-E ecotropic packaging cells (Morita et al. 2000) were transfected with retroviral plasmids by calcium phosphate precipitation. Two days after transfection, supernatants were collected and supplemented with $8 \mu \mathrm{g} / \mathrm{mL}$ polybrene (Sigma) for T-cell transductions.

\section{In vitro culture of $C D 4^{+}$T cells}

Purified CD $4^{+} \mathrm{T}$ cells were activated in vitro with $5 \mu \mathrm{g} / \mathrm{mL}$ platebound anti-CD3 and $1 \mu \mathrm{g} / \mathrm{mL}$ soluble anti-CD28 antibodies (eBiosciences) in RPMI supplemented with $10 \%$ FCS, $5 \mathrm{mM}$ $\beta$-mecaptoethanol, and antibiotics. Cells were plated at a density of $5 \times 10^{5}$ per milliliter at day 0 of culture. For transductions, viral supernatants were added to the cells $24 \mathrm{~h}$ after activation, and centrifuged at $2500 \mathrm{rpm}$ for $1.5 \mathrm{~h}$ at $30^{\circ} \mathrm{C}$.

\section{CD4 ${ }^{+}$T-cell transfer}

CD45.1 and CD45.2 congenically marked cells were mixed at a 1:1 ratio and resuspended in PBS at $5 \times 10^{7}$ cells per milliliter. 
Chong et al.

A total of $5 \times 10^{6}$ cells were transferred into $\mathrm{Rag}^{-/-}$recipients by injection into the retro-orbital plexus.

ChIP

Purified cells were cross-linked with $1 \%$ formaldehyde for 10 min at room temperature. Cross-linking was stopped by the addition of glycine to a final concentration of $0.125 \mathrm{M}$, and the cells were washed once in cold PBS. Nuclei were prepared by resuspending cells in $50 \mathrm{mM}$ HEPES-KOH $(\mathrm{pH} 7.5), 140 \mathrm{mM}$ $\mathrm{NaCl}, 1 \mathrm{mM}$ EDTA, $10 \%$ glycerol, $0.5 \% \mathrm{NP}-40$, and $0.25 \%$ Triton X-100 (lysis buffer 1), and gently rocking for $10 \mathrm{~min}$ at $4^{\circ} \mathrm{C}$. Nuclei were washed for $10 \mathrm{~min}$ at room temperature in $10 \mathrm{mM}$ Tris- $\mathrm{HCl}$ (pH 8.0), $200 \mathrm{mM} \mathrm{NaCl}, 1 \mathrm{mM}$ EDTA, and $0.5 \mathrm{mM}$ EGTA (lysis buffer 2). The nuclei were then pelleted and resuspended in $10 \mathrm{mM}$ Tris- $\mathrm{HCl}(\mathrm{pH} 8.0), 100 \mathrm{mM} \mathrm{NaCl}$, $1 \mathrm{mM}$ EDTA, $0.5 \mathrm{mM}$ EGTA, $0.1 \%$ sodium deoxycholate, and $0.5 \%$ N-lauroylsarcosine (lysis buffer 3 ) at a concentration of $3.3 \times 10^{7}$ nuclei per milliliter. Nuclear lysates were sonicated using a Bioruptor (Diagenode) to create chromatin fragments in the range of 100-600 bp. Triton X-100 was added to a final concentration of $1 \%$, and samples were spun at $14,000 \mathrm{rpm}$ for $10 \mathrm{~min}$ to remove debris. One percent of the input was set aside in order to determine the quantity of immunoprecipitation. For immunoprecipitation, $3 \times 10^{6}$ cell equivalents of sheared chromatin were incubated with $50 \mu \mathrm{L}$ of protein G Dynabeads (Dynal, Invitrogen), which were prebound with $5 \mu \mathrm{g}$ of antibody (see Supplemental Table S1), in $500 \mu \mathrm{L}$ of lysis buffer 3 overnight at $4{ }^{\circ} \mathrm{C}$. The next day, beads were washed once with $20 \mathrm{mM}$ Tris$\mathrm{HCl}(\mathrm{pH} 8), 150 \mathrm{mM} \mathrm{NaCl}, 2 \mathrm{mM}$ EDTA, $1 \%$ Triton X-100, and $0.1 \%$ SDS; once with $20 \mathrm{mM}$ Tris- $\mathrm{HCl}(\mathrm{pH} 8), 500 \mathrm{mM} \mathrm{NaCl}$, 2 mM EDTA, $1 \%$ Triton X-100, and $0.1 \%$ SDS; five times with $2.5 \mathrm{mM}$ HEPES-KOH (pH 7.6), $500 \mathrm{mM} \mathrm{LiCl}, 1 \mathrm{mM}$ EDTA, $1 \%$ NP-40, and $0.7 \%$ sodium deoxycholate; and once with TE/50 $\mathrm{mM} \mathrm{NaCl}$. Immunoprecipitated chromatin was subsequently eluted with $200 \mu \mathrm{L}$ of $50 \mathrm{mM}$ Tris- $\mathrm{HCl}(\mathrm{pH}$ 8), 10 mM EDTA, and $1 \%$ SDS by heating for $1 \mathrm{~h}$ at $65^{\circ} \mathrm{C}$. Eluted samples were transferred to new tubes and incubation at $65^{\circ} \mathrm{C}$ was continued overnight for both ChIP and input samples to reverse protein-DNA cross-links. Samples were treated with $0.2 \mathrm{mg} / \mathrm{mL}$ RNase, followed by $0.2 \mathrm{mg} / \mathrm{mL}$ Proteinase $\mathrm{K}$, and DNA was purified by phenol/chlorophorm extraction and EtOH precipitation. Chromatin-immunopreciptated and input DNA were analyzed by quantitative PCR using the Bio-Rad iCycler and the Roche LightCycler 480II. Locus-specific primers are listed in Supplemental Table S2. ChIP data were calculated as percent of input. This was then normalized to total H3 ChIP percent of input to account for variations in nucleosome density. Thus, an index of 1 indicates that $100 \%$ of $\mathrm{H} 3$ at that genomic region carries the modification that is chromatin-immunoprecipitated.

\section{Acknowledgments}

M.M.W.C. was funded sequentially by a Post-doctoral Fellowship from the Cancer Research Institute and a Senior Fellowship from the Helen and Martin Kimmel Center for Stem Cell Biology. M.C. was funded by a Post-doctoral Fellowship from the Leukemia and Lymphoma Society. This work was supported by the Howard Hughes Medical Institute (D.R.L.).

\section{References}

Adlam M, Siu G. 2003. Hierarchical interactions control CD4 gene expression during thymocyte development. Immunity 18: $173-184$.
Barndt R, Dai MF, Zhuang Y. 1999. A novel role for HEB downstream or parallel to the pre-TCR signaling pathway during $\alpha \beta$ thymopoiesis. I Immunol 163: 3331-3343.

Barski A, Cuddapah S, Cui K, Roh TY, Schones DE, Wang Z, Wei G, Chepelev I, Zhao K. 2007. High-resolution profiling of histone methylations in the human genome. Cell 129: 823837.

Berg LJ, Kang J. 2001. Molecular determinants of TCR expression and selection. Curr Opin Immunol 13: 232-241.

Cavilli G, Paro R. 1998. The Drosophia Fab-7 chromosomal element conveys epigenetic inheritance during mitosis and meiosis. Cell 93: 505-518.

Collins A, Littman DR, Taniuchi I. 2009. RUNX proteins in transcription factor networks that regulate T-cell lineage choice. Nat Rev Immunol 9: 106-115.

Ellmeier W, Sunshine MJ, Losos K, Hatam F, Littman DR. 1997. An enhancer that directs lineage-specific expression of CD8 in positively selected thymocytes and mature T cells. Immunity 7: 537-547.

Ellmeier W, Sunshine MJ, Losos K, Littman DR. 1998. Multiple developmental stage-specific enhancers regulate CD8 expression in developing thymocytes and in thymus-independent T cells. Immunity 9: 485-496.

Feik N, Bilic I, Tinhofer J, Unger B, Littman DR, Ellmeier W. 2005. Functional and molecular analysis of the doublepositive stage-specific CD8 enhancer E8III during thymocyte development. J Immunol 174: 1513-1524.

Gillespie FP, Doros L, Vitale J, Blackwell C, Gosselin J, Snyder BW, Wadsworth SC. 1993. Tissue-specific expression of human CD4 in transgenic mice. Mol Cell Biol 13: 29522958.

Hanna Z, Simard C, Laperriere A, Jolicoeur P. 1994. Specific expression of the human $\mathrm{CD} 4$ gene in mature $\mathrm{CD} 4^{+} \mathrm{CD} 8^{-}$ and immature $\mathrm{CD}^{+} \mathrm{CD}^{+} \mathrm{T}$ cells and in macrophages of transgenic mice. Mol Cell Biol 14: 1084-1094.

He X, He X, Dave VP, Zhang Y, Hua X, Nicolas E, Xu W, Roe BA, Kappes DJ. 2005. The zinc finger transcription factor ThPOK regulates CD4 versus CD8 T-cell lineage commitment. Nature 433: 826-833.

He X, Park K, Wang H, He X, Zhang Y, Hua X, Li Y, Kappes DJ. 2008. CD4-CD8 lineage commitment is regulated by a silencer element at the ThPOK transcription-factor locus. Immunity 28: 346-358.

Heintzman ND, Stuart RK, Hon G, Fu Y, Ching CW, Hawkins RD, Barrera LO, Van Calcar S, Qu C, Ching KA, et al. 2007. Distinct and predictive chromatin signatures of transcriptional promoters and enhancers in the human genome. Nat Genet 39: 311-318.

Hostert A, Tolaini M, Roderick K, Harker N, Norton T, Kioussis D. 1997. A region in the CD8 gene locus that directs expression to the mature CD8 $\mathrm{T}$ cell subset in transgenic mice. Immunity 7: 525-536.

Hostert A, Garefalaki A, Mavria G, Tolaini M, Roderick K, Norton T, Mee PJ, Tybulewicz VL, Coles M, Kioussis D. 1998. Hierarchical interactions of control elements determine CD $8 \alpha$ gene expression in subsets of thymocytes and peripheral T cells. Immunity 9: 497-508.

Ivanov II, Diehl GE, Littman DR. 2006. Lymphoid tissue inducer cells in intestinal immunity. Curr Top Microbiol Immunol 308: $59-82$.

Jones ME, Zhuang Y. 2007. Acquisition of a functional T cell receptor during $\mathrm{T}$ lymphocyte development is enforced by HEB and E2A transcription factors. Immunity 27: 860-870.

Keefe R, Dave V, Allman D, Wiest D, Kappes DJ. 1999. Regulation of lineage commitment distinct from positive selection. Science 286: 1149-1153. 
Keppler OT, Welte FJ, Ngo TA, Chin PS, Patton KS, Tsou CL, Abbey NW, Sharkey ME, Grant RM, You Y, et al. 2002. Progress toward a human CD4/CCR5 transgenic rat model for de novo infection by human immunodeficiency virus type 1. J Exp Med 195: 719-736.

Killeen N, Sawada S, Littman DR. 1993. Regulated expression of human CD4 rescues helper T cell development in mice lacking expression of endogenous CD4. EMBO J 12: 1547-1553.

Kim D, Mebius RE, MacMicking JD, Jung S, Cupedo T, Castellanos Y, Rho J, Wong BR, Josien R, Kim N, et al. 2000. Regulation of peripheral lymph node genesis by the tumor necrosis factor family member TRANCE. I Exp Med 192: 1467-1478.

Manjunath N, Shankar P, Stockton B, Dubey PD, Lieberman I, von Andrian UH. 1999. A transgenic mouse model to analyze $\mathrm{CD}^{+}$effector $\mathrm{T}$ cell differentiation in vivo. Proc Natl Acad Sci 96: 13932-13937.

Maurange C, Paro R. 2002. A cellular memory module conveys epigenetic inheritance of hedgehog expression during Drosophia wing imaginal disc development. Genes \& Dev 16: 2672-2683.

Mebius RE. 2003. Organogenesis of lymphoid tissues. Nat Rev Immunol 3: 292-303.

Morita S, Kojima T, Kitamura T. 2000. Plat-E: An efficient and stable system for transient packaging of retroviruses. Gene Ther 7: 1063-1066.

Naoe Y, Setoguchi R, Akiyama K, Muroi S, Kuroda M, Hatam F, Littman DR, Taniuchi I. 2007. Repression of interleukin-4 in $\mathrm{T}$ helper type 1 cells by Runx/Cbf $\beta$ binding to the Il4 silencer. J Exp Med 204: 1749-1755.

Pelegri F, Lehmann R. 1994. A role of polycomb group genes in the regulation of gap gene expression in Drosophila. Genetics 136: 1341-1353.

Raisner RM, Hartley PD, Meneghini MD, Bao MZ, Liu CL, Schreiber SL, Rando OJ, Madhani HD. 2005. Histone variant H2A.Z marks the $5^{\prime}$ ends of both active and inactive genes in euchromatin. Cell 123: 233-248.

Sawada S, Littman DR. 1991. Identification and characterization of a T-cell-specific enhancer adjacent to the murine CD4 gene. Mol Cell Biol 11: 5506-5515.

Sawada S, Littman DR. 1993. A heterodimer of HEB and an E12related protein interacts with the CD4 enhancer and regulates its activity in T-cell lines. Mol Cell Biol 13: 5620-5628.

Sawada S, Scarborough JD, Killeen N, Littman DR. 1994. A lineage-specific transcriptional silencer regulates CD4 gene expression during T lymphocyte development. Cell 77: 917929.

Setoguchi R, Tachibana M, Naoe Y, Muroi S, Akiyama K, Tezuka C, Okuda T, Taniuchi I. 2008. Repression of the transcription factor Th-POK by Runx complexes in cytotoxic T cell development. Science 319: 822-825.

Singer A. 2002. New perspectives on a developmental dilemma: The kinetic signaling model and the importance of signal duration for the CD4/CD8 lineage decision. Curr Opin Immunol 14: 207-215.

Siu G, Wurster AL, Duncan DD, Soliman TM, Hedrick SM. 1994. A transcriptional silencer controls the developmental expression of the CD4 gene. EMBO J 13: 3570-3579.

Sun G, Liu X, Mercado P, Jenkinson SR, Kypriotou M, Feigenbaum L, Galera P, Bosselut R. 2005. The zinc finger protein cKrox directs CD4 lineage differentiation during intrathymic T cell positive selection. Nat Immunol 6: 373-381.

Taniuchi I, Osato M, Egawa T, Sunshine MJ, Bae SC, Komori T, Ito Y, Littman DR. 2002. Differential requirements for Runx proteins in CD4 repression and epigenetic silencing during $\mathrm{T}$ lymphocyte development. Cell 111: 621-633.
Wei G, Wei L, Zhu J, Zang C, Hu-Li J, Yao Z, Cui K, Kanno Y, Roh TY, Watford WT, et al. 2009. Global mapping of H3K4me3 and H3K27me3 reveals specificity and plasticity in lineage fate determination of differentiating $\mathrm{CD}^{+} \mathrm{T}$ cells. Immunity 30: 155-167.

Wolfer A, Bakker T, Wilson A, Nicolas M, Ioannidis V, Littman DR, Lee PP, Wilson CB, Held W, MacDonald HR, et al. 2001. Inactivation of Notch 1 in immature thymocytes does not perturb CD4 or CD8T cell development. Nat Immunol 2: 235-241.

Yamashita M, Hirahara K, Shinnakasu R, Hosokawa $\mathrm{H}$, Norikane S, Kimura MY, Hasegawa A, Nakayama T. 2006. Crucial role of MLL for the maintenance of memory T helper type 2 cell responses. Immunity 24: 611-622.

Yu BD, Hess JL, Horning SE, Brown GA, Korsmeyer SJ. 1995. Altered Hox expression and segmental identity in Mllmutant mice. Nature 378: 505-508.

Zheng Y, Josefowicz S, Chaudhry A, Peng XP, Forbush K, Rudensky AY. 2010. Role of conserved non-coding DNA elements in the Foxp3 gene in regulatory T-cell fate. Nature 463: 808-812.

Zou YR, Sunshine MJ, Taniuchi I, Hatam F, Killeen N, Littman DR. 2001. Epigenetic silencing of CD4 in T cells committed to the cytotoxic lineage. Nat Genet 29: 332-336. 


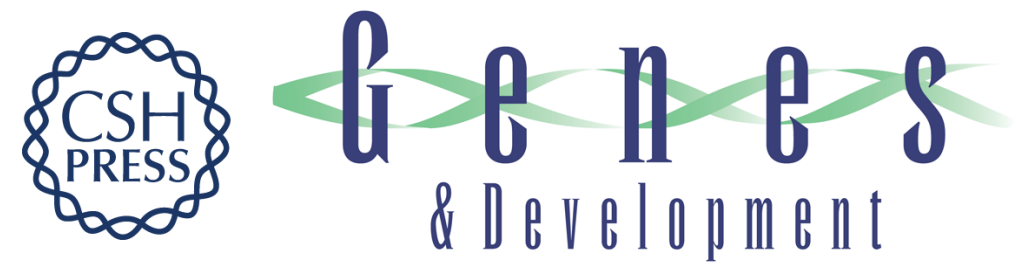

\section{Epigenetic propagation of CD4 expression is established by the Cd4 proximal enhancer in helper $\mathrm{T}$ cells}

Mark M.W. Chong, Natalie Simpson, Maria Ciofani, et al.

Genes Dev. 2010, 24:

Access the most recent version at doi:10.1101/gad.1901610

\section{Supplemental http://genesdev.cshlp.org/content/suppl/2010/03/31/24.7.659.DC1 Material}

Related Content

Memories of lost enhancers

Ranjan Sen and Rudolf Grosschedl

Genes Dev. May , 2010 24: 973-979

References This article cites 43 articles, 13 of which can be accessed free at: http://genesdev.cshlp.org/content/24/7/659.full.htmI\#ref-list-1

Articles cited in:

http://genesdev.cshlp.org/content/24/7/659.full.html\#related-urls

\section{License}

Email Alerting Receive free email alerts when new articles cite this article - sign up in the box at the top Service right corner of the article or click here.

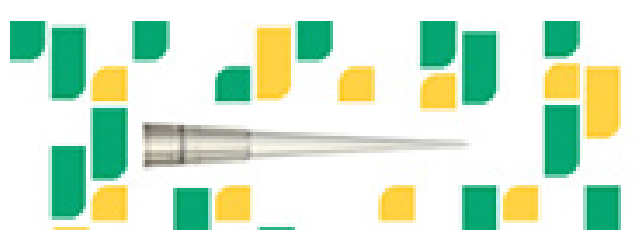

Focused on your science. 